\title{
Ośrodek Badań Historii Kobiet w Białymstoku
}

https://doi.org/10.34739/clit.2021.15.27

Studia nad kobiecością, badania dziejów kobiet, różnodyscyplinowe podejścia do problematyki kobiecej rozwijają się w Polsce od wielu już lat. Okazuje się, że nadal pojawiają się nowe pomysły, trendy, metody, przybliżane są zapomniane, a odkrywane nieznane osoby. Zapotrzebowanie na poszukiwanie, zgłębianie, reiterpretację wspomnianych zagadnień nie słabnie, a raczej się nasila, co należy ocenić jako pozytywne działanie.

Przykładem instytucji zajmującej się omawianą tematyką, ze szczególnym naciskiem na dzieje kobiet, jest powstały jako przedsięwzięcie grantowe MNiSW Ośrodek Badań Historii Kobiet w Białymstoku (w ramach programu DIALOG, na lata 2019-2021; nr 0016/DLG/2019/10). Jest on częścią, istniejącego od 2011 roku, Instytutu Studiów Kobiecych w Białymstoku, zrzeszającego ogólnopolskie i zagraniczne środowisko naukowe, głównie akademickie, upowszechniającego badania naukowe nad tematyką kobiecą oraz realizującego projekty naukowe, edukacyjne czy kulturalne o zasięgu regionalnym, krajowym i międzynarodowym. Pomysłodawczynią i inicjatorką oraz prezesem zarządu ISK jest prof. dr hab. Małgorzata Dajnowicz, kierownik Zakładu Historii Kultury, Myśli i Ruchów Społecznych Uniwersytetu w Białymstoku oraz Podlaska Wojewódzka Konserwator Zabytków.

W skład zespołu Ośrodka wchodzą specjaliści, badacze, koncentrujący swoje wysiłki naukowe w dużej mierze na historii kobiet oraz dziejach prasy, w tym prasy dla kobiet. Są to zarówno doświadczeni pracownicy z różnych uczelni, jak i ludzie młodzi, asystenci i adiunkci. W Ośrodku podejmowane są badania, skupiające się m.in.: na dziejach kobiet na tle porównawczym, wkładzie polskich dziennikarek w budowanie przestrzeni kulturalnej rodaków na emigracji, narracjach osobistych kobiet z XIX i XX wieku, prasie 
dla kobiet w II RP i po 1945 roku, kobiecych organizacjach społecznych do wybuchu II wojny światowej, czy aktywności kobiet w strukturach politycznych do lat 90. XX wieku. Wyniki prowadzonej działalności naukowej ekspertów Instytutu czy Ośrodka prezentowane są na różnych organizowanych konferencjach naukowych, seminariach i sympozjach, także podczas cyklicznych Białostockich Szkół Historii Kobiet. To orgaznizowane latem spotkania mistrzów i uczniów, profesorów, doktorów, doktorantów, z kraju i zagranicy - debaty tematyczne, warsztaty metodyczne, dyskusje nad wynikami własnych osiągnięć naukowych w gronie specjalistów z różnych dyscyplin.

W ramach projektu MNISW w Ośrodku Badań Historii Kobiet zorganizowano już kilkanaście takich spotkań:

- 25 października 2019 r. - I Spotkanie robocze Członków Zespołu i współpracowników Ośrodka Badań Historii Kobiet Instytutu Studiów Kobiecych, pt.: Kierunki badań historii kobiet w Polsce - stan badań i perspektywy na przykładzie wybranych zagadnień.

- 21-25 listopada 2019 r. - I Spotkanie Białostockiej Szkoły Historii Kobiet, pt.: Badania historii kobiet w Polsce - kierunki, perspektywy.

- 13 grudnia 2019 r. - II Spotkanie Członków Zespołu i Współpracowników Ośrodka Badań Historii Kobiet, pt.: Badania naukowe z zakresu dziejów kobiet XXX w. białostockiego ośrodka naukowego (tradycje, stan badań i perspektywy na przykładzie wybranych zagadnień).

- 13 grudnia 2019 r. - II Spotkanie Członków Zespołu i Współpracowników Ośrodka Badań Historii Kobiet, pt.: Badania naukowe z zakresu dziejów kobiet XXX w. białostockiego ośrodka naukowego (tradycje, stan badań i perspektywy na przykładzie wybranych zagadnień).

- 7-8 luty 2020 r. - III Spotkanie Członków Zespołu i Współpracowników Ośrodka Badań Historii Kobiet, pt.: Źródła i metody badań historii kobiet.

- 24 lipca -2 sierpnia 2020 r. - Białostocka Letnia Szkoła Historii Kobiet pt. Badania historii kobiet w Polsce - na przykładzie projektów badawczych indywidualnych i zespołowych.

- 11-14 września 2020 r. - ogólnopolska konferencja naukowa Ruchy kobiece na ziemiach polskich w XIX i XX w. Stan badań i perspektywy (na tle porównawczym). 
- 23 października 2020 r. - IV Spotkanie Członków Zespołu i Współpracowników Ośrodka Badań Historii Kobiet, pt.: Metodologia badań historii kobiet i jej wykorzystywanie $\mathrm{w}$ badaniach nauk humanistycznych (na przykładzie prasy dla kobiet).

- 12 grudnia 2020 r. - V Spotkanie Członków Zespołu i Współpracowników Ośrodka Badań Historii Kobiet, pt.: Osiągnięcia naukowe Ośrodka Badań Historii Kobiet 2019-2020. Stan obecny i perspektywy.

- 17 kwietnia 2021 r. - VI Spotkanie Członków Zespołu i Współpracowników Ośrodka Badań Historii Kobiet, pt.: Dziennikarki, publicystki, kobiety piszące. Twórczynie przekazu źródłowego o dziejach kobiet.

- 11-13 czerwca 2021 r. - ogólnopolska konferencja naukowa pt. Badania historii kobiet polskich na tle porównawczym. Kierunki, problematyka, perspektywy.

- Augustów 18-24 sierpnia 2021 r. - Białostocka Letnia Szkoła Historii Kobiet pt. Badania historii kobiet w Polsce, cz. II.

Ośrodek Badań Historii Kobiet upowszechnia również swoje osiągnięcia i wyniki naukowe na łamach „Czasopisma Naukowego Instytutu Studiów Kobiecych”, włączając się tym samym do dyskusji naukowej nad problematyką kobiecą. Czasopismo, znajdujące się na liście ministerialnej, ma charakter interdyscyplinarny, artykuły ukazujące się w nim obejmują tematykę historyczną, prasoznawczą, literaturoznawczą, kulturoznawczą, socjologiczną czy z zakresu nauk o polityce.

Warto dodać, że przedsięwzięciom naukowym towarzyszą wydarzenia artystyczne: wystawa „Podwójnie wolne. Prawa polityczne kobiet 1918 (czerwiec 2019)" - to wystawa ukazująca historie chrześcijańskich demokratek, feministek i rewolucjonistek, których działalność przyczyniła się do przyznania praw wyborczych Polkom w 1918 roku oraz „Pionierki. Kobiety w edukacji i nauce (wrzesień 2020-maj 2021)" - wystawa popularyzująca osiągnięcia kobiet polskich, prekursorek w edukacji, w tym akademickiej, nowatorek w osiągnięciach naukowych, pokazująca wkład Polek w rozwój dydaktyki i nauki w Polsce i na świecie. 